\title{
Future prospects for Nearctic migrants wintering in Caribbean forests
}

\author{
JOSEPH M. WUNDERLE, JR and ROBERT B. WAIDE
}

\section{Summary}

Wintering Nearctic migrants constitute a high proportion of the birds present in many terrestrial habitats in the Bahamas and Greater Antilles, but their proportions decline southward through the Lesser Antilles. Many migrants winter on densely populated islands which have been extensively deforested. Current estimates show that only $21 \%$ of the land area, or approximately five million hectares, remain in forest on Caribbean and Bahamian islands, indicating that most of the major deforestation has already occurred. Although reforestation is under way on a few islands, many remnant forest fragments are threatened by humans or natural disturbances such as drought or hurricanes. Thus wintering migrants requiring closed-canopy forest are at greatest risk to habitat loss, whereas species requiring early successional habitats are not currently threatened, assuming that pesticide use does not increase. Policies which protect forests, particularly mangroves, wet limestone and montane broadleaf forests in the Greater Antilles, and broadleaf scrub ("coppice") in the Bahamas, will be beneficial to migrants and endemic species.

Las aves migratorias neárticas invernantes constituyen una alta proporción de las aves presentes en numerosos hábitats terrestres de las Bahamas y de las Antillas Mayores, pero sus proporciones disminuyen hacia el sur a traves de las Antillas Menores. Muchos migrantes invernan en islas densamente pobladas que han sido deforestadas extensivamente. Estimas actuales muestran que sólo el 21\% del área terrestre, o aproximadamente cinco millones de hectáreas, permanecen arboladas en las islas del Caribe y las Bahamas, indicando que la mayor parte de la deforestación ya ha ocurrido. Aún cuando cierta reforestación se está llevando a cabo en unas pocas islas, los fragmentos restantes de bosque están amenazados por el hombre o por disturbios naturales tales como huracanes o sequías. Por lo tanto, las aves migratorias que requieren bosque con un dosel cerrado están en mayor riesgo de perder su hábitat, mientras que las especies que requieren etapas tempranas de sucesión no están amenazadas en el presente, asumiendo que el uso de pesticidas no aumente. Las políticas públicas que protejan los bosques, particularmente manglares, bosques latifolios montanos y bosques húmedos de piedra caliza en las Antillas Mayores, y matorral latifolio ("coppice") en las Bahamas serán beneficiosas para las aves migratorias y residentes por igual. 


\section{Introduction}

Current concern regarding the fate of Neotropical migrant landbirds arises from studies indicating that some population declines are associated with deforestation on either the North American breeding grounds or on the tropical wintering grounds (reviewed in Askins et al. 1990). While recent local declines can mostly be attributed to the negative consequences of forest fragmentation on the breeding grounds (Wilcove and Robinson 1990), the high rate of deforestation in Middle America and the Caribbean (Lanly 1982) is likely to have a greater impact on migrant populations in the future (Rappole and Powell 1986). Therefore, major land-use changes in Mexico, Central America, and the islands of the Bahamas and Caribbean could be particularly detrimental to migrants, as most overwinter in close proximity to the southern U.S.A. (Keast 1980).

In the Caribbean, several circumstances contribute to a precarious situation for native forests (Lugo et al. 1981). Most Caribbean islands are small and densely populated, resulting in extensive deforestation and degradation of remnant forest fragments. Moreover, many islands have steep topographic and climatic gradients producing a diversity of forest types in a relatively small area, further increasing the potential vulnerability of organisms restricted to specific forest types. Not only are many forest patches under increasing pressure from human disturbance, but frequent natural disturbances such as droughts and hurricanes may further compound the negative effects of man. Thus, given all these pressures on island forests, it is not surprising that the Caribbean islands account for the highest rates of animal extinction in historical times (Cruz and Fairbain 1980).

Wintering Nearctic migrants are often abundant and widespread throughout a variety of terrestrial habitats in the Bahamas and Caribbean (Lack and Lack 1972, Emlen 1977, 1980, Terborgh and Faaborg 1980, Pashley 1988a,b, 1990, Askins et al. 1992, Wunderle and Waide 1993). Because many species of migrants overwinter in the forests of this region, the future value of the region as a wintering ground is dependent on the extent and condition of these forests. To assess the future prospects for wintering migrants in the Bahamas and insular Caribbean we summarize the characteristics of the region's forests and discuss the prospects for individual species. Finally we provide recommendations for migrant conservation efforts in the region based on our own experience and surveys throughout the Bahamas and Greater Antilles (Wunderle and Waide 1993).

\section{Migrant distribution in the Caribbean}

Wintering Nearctic migrants constitute a very high proportion of the birds present in many of the habitats in the Bahamas and Greater Antilles, but their proportions decline through the Lesser Antilles (Figure 1). This pattern was noted by Terborgh and Faaborg (1980), who argued that southbound migrants were faced with diminishing returns by flying farther and farther to smaller and smaller targets. Although this might be an important explanation for the relative absence of wintering migrants in the Lesser Antilles, it does not explain the wide variation in migrant abundance among habitats on the same islands in the 


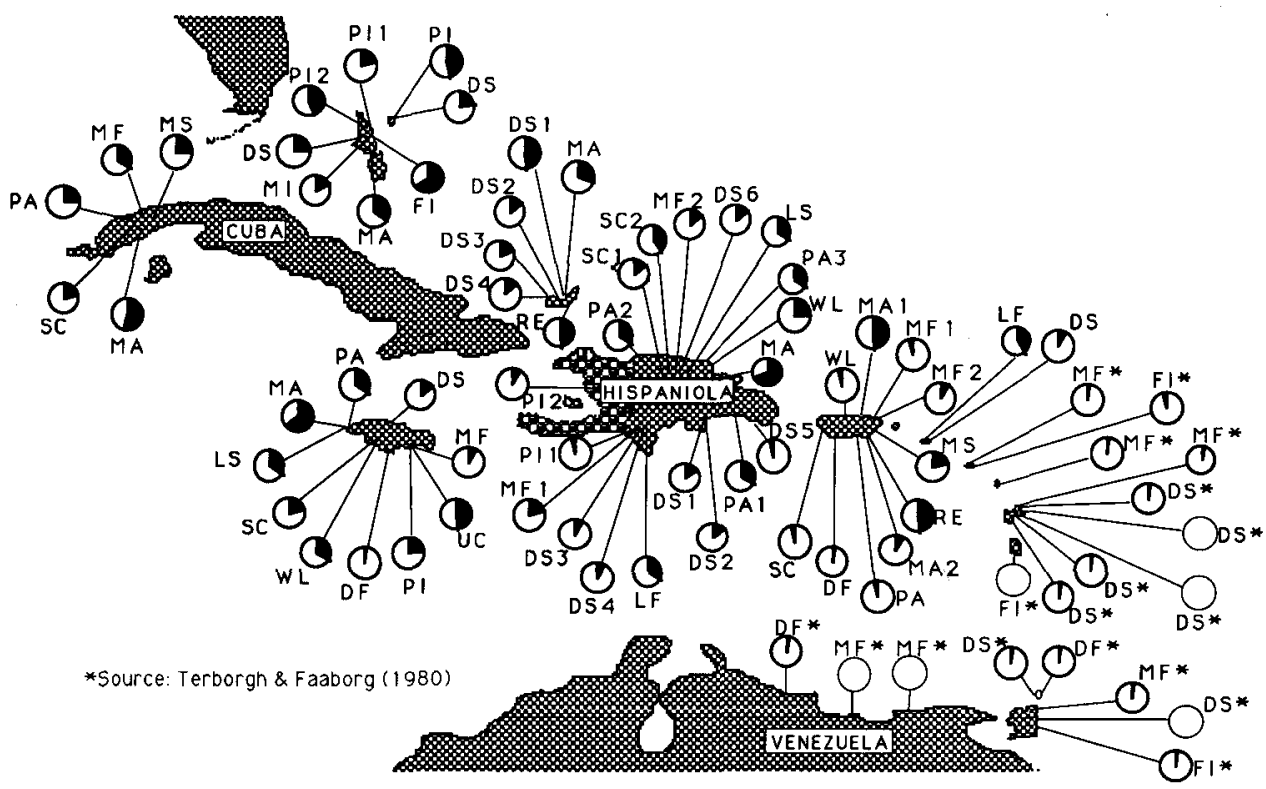

Figure 1. Percentage of Nearctic migrants in samples of birds surveyed in different habitats in the Caribbean. Samples from the Bahamas (Andros, Great Inagua, New Providence) and Greater Antilles (Cuba, Jamaica, Dominican Republic, Puerto Rico, St John) were obtained from fixed radius point counts by Wunderle and Waide (1993). Samples from the Lesser Antilles, Trinidad and Tobago, and Venezuela were obtained from mist-netting by Terborgh and Faaborg (1980). The black portion of each circle indicates the percentage of migrants in a sample of birds from habitats designated by a two letter code: DS, dry limestone scrub; DF, dry limestone forest; FI, brushy field; LF, lowland forest edge, LS, lowland second growth; MA, mangrove; MI, mixed pine and scrub; MF, montane broadleaf forest; MS, montane second growth; PA, pasture; PI, pine; RE, residential; SC, shade coffee; UC, sun coffee; WL, wet limestone forest. Habitats sampled in more than one location on the same island are indicated by numbers.

Bahamas and Greater Antilles. For example, in the Greater Antilles mangroves consistently contain high proportions of migrants, whereas xeric habitats (dry scrub or dry forest) have the lowest proportions of migrants. These trends were also found in counts of total migrant individuals (Wunderle and Waide 1993).

Migrant species richness does not decline with distance from North America or with island size, at least through the Bahamas and Greater Antilles (Figure 2). In contrast to relative migrant abundance, migrant species richness is sometimes high in xeric habitats and low in mangroves (Figure 2). We have listed the species of terrestrial Nearctic migrants and the habitats in which they were encountered during our surveys in the Bahamas and Greater Antilles in the Appendix.

\section{Species of special concern}

Previous searches for Kirtland's Warblers Dendroica kirtlandii in the Bahamas have largely been unsuccessful (one bird in 800 hours of fieldwork on 11 islands: Radabaugh 1974; none in 500 hours on Grand Bahama Island: Emlen 1977), as 


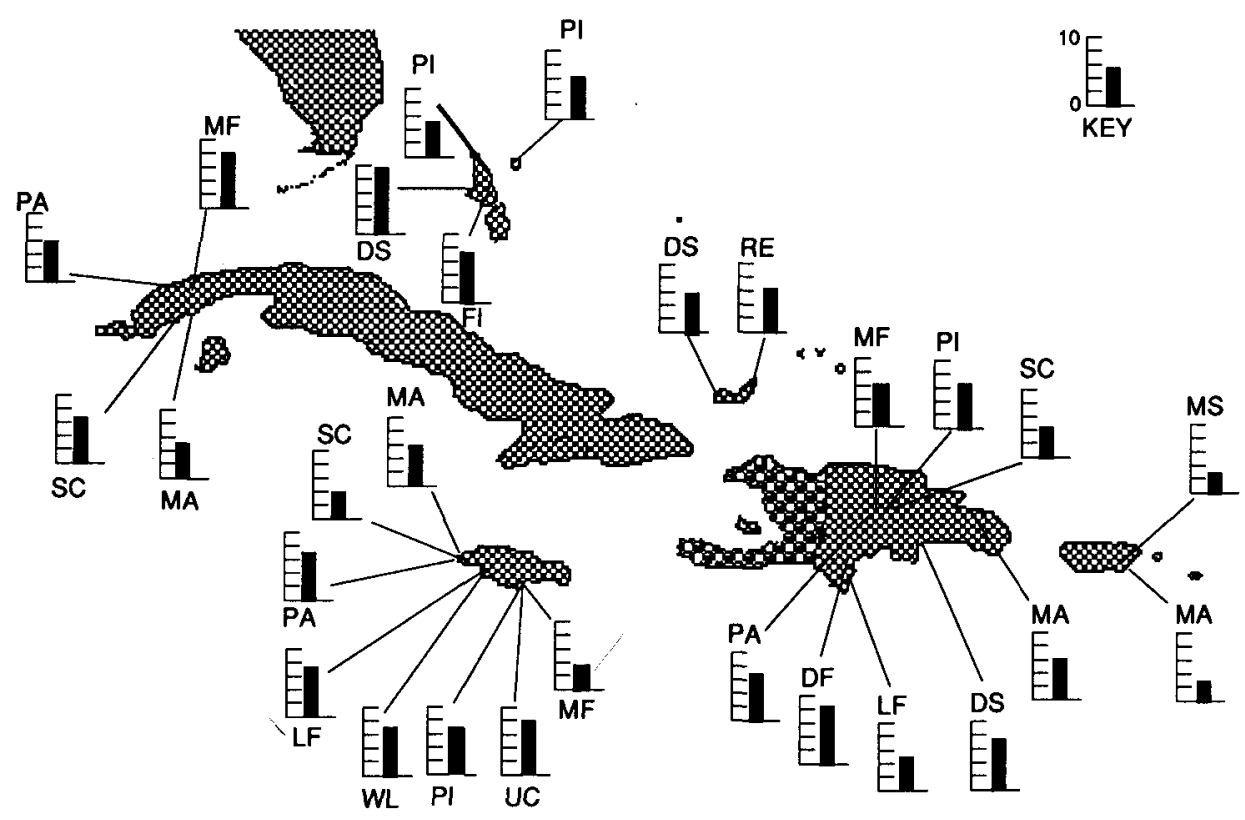

Figure 2. Number of Nearctic migrant species estimated by rarefaction from a sample of 20 migrant individuals observed during point counts. Key in upper right shows scale with the bar indicating five species. Two letter habitat code is explained in the caption to Figure 1 .

were ours (Wunderle and Waide 1993). We failed to detect it during 411 point counts and 787 net-hours on three Bahamian Islands where it has been recorded. Nor did we detect it after 616 point counts and 1,308 net-hours in the Dominican Republic, a location of other sight records (W. Arendt pers. comm., Faanes and Haney 1989). Bachman's Warbler Vermivora bachmani was also not found, despite 152 point counts and 872 net-hours in western Cuba, particularly in the Sierra del Rosario, where the species has been observed (Hamel 1986). Swainson's Warbler (see Appendix for other scientific names) was not detected during point counts, but was captured by mist-nets in dry limestone scrub on Andros (one individual in 261 net-hours), and in mangroves (two individuals in 121 net-hours), and montane broadleaf forest on Jamaica (two individuals in 196 net-hours). Approximately four months after Hurricane Gilbert (January 1989) we found it only in dry limestone forest on Jamaica (one individual in 140 net-hours). The report of 13 Swainson's Warblers trapped in the 1990 field season in Cuba suggests that Cuba may be an island of particular importance to this species in the Caribbean (Hyslop 1991).

\section{Characteristics of Caribbean forests}

Temperature, rainfall and their seasonal variation are major determinants of the pattern of the world's vegetation and provide a basis for its classification into life zones. Holdridge's (1972) system recognizes 120 life zones, with approximately 68 in the subtropics or tropics, of which 30 are forested. Thirteen life zones are represented in the entire insular Caribbean (Lugo et al. 1981), compared 
with 12 in the relatively small country of Costa Rica (Hartshorn 1983). Within an island, life zones often cover a small area owing to the small size and steep topography of many Caribbean islands. The diversity of life zones within the Caribbean varies with island size and topographic relief. This is illustrated by the presence of nine life zones on the large mountainous (maximum elevation 3,200 m) island of Hispaniola (Holdridge 1972); six life zones on the smaller, less mountainous (maximum elevation 1,350 m) island of Puerto Rico (Ewel and Whitmore 1973), and two life zones in the small, low-lying (maximum elevation $540 \mathrm{~m}$ ) Virgin Islands (Ewel and Whitmore 1973). The diversity of Caribbean flora and forest types vary in a corresponding manner.

Although island floras are expected to be less diverse than those of corresponding area and latitude on the continent (MacArthur and Wilson 1967), only the smallest low-lying islands can be characterized as depauperate. For many Caribbean islands the floral diversity can be relatively high. For example, Beard (1949) lists 2,000 species of flowering plant, 243 tree species, and 13 different forest formations in the Windward and Leeward Islands. An incomplete flora of the Dominican Republic lists 5,600 species (Jiménez 1959), while 6,000 species are recorded for Cuba (Woods 1989). On Puerto Rico alone there are 547 species of native trees (Little et al. 1974). Even on the same island, forests can vary in composition from a few tree species (mangroves) to over a hundred tree species (e.g. 153 species in the tabonuco forest type on Puerto Rico: Little and Woodbury 1976).

We have summarized the estimates of the extent of Caribbean forests from a variety of sources (Table 1 ). Considerable variation exists among these estimates, as different methods and assumptions were involved. Studies differ in the definition of forest cover based on the amount of canopy closure, and human disturbance by slash-and-burn agriculture, fire or charcoal-cutting. In addition, the most recent estimate for the Bahamas includes only pine forest, thereby ignoring broadleaf scrub woodland ("coppice") and including only the northern islands of Grand Bahama, Andros, Abaco and New Providence (to which pine is restricted). Pine and broadleaf are incorporated in the èstimates for the remaining islands in which pine is native, including Cuba (36\% of forest area is pine: FAO 1991), Haiti (pine and broadleaf not separated), and the Dominican Republic (21\% of forest area is pine: FAO 1991). Thus these estimates of forest cover must be used with extreme caution.

Despite the limitations of the estimates of forest cover, it is evident that Caribbean forests have diminished drastically since the arrival of the first Europeans. For example, using the highest available estimates of forest cover during the 1980 , or the most recent estimate, we find that the weighted average for the ratio of forest to total land area is $21 \%$ and that forests currently cover $4,990,440$ ha on the Caribbean islands. Even if this figure is off by $10-15 \%$, it is still apparent that most of the major deforestation has already occurred in the Caribbean. For lowland forests, much of the clearing occurred in the period 1630-1880, during the major period of sugarcane cultivation, whereas many upland forests were cleared for agriculture from the 188 os to the 1940s (Lugo et al. 1981).

Forest loss has not occurred equally across all life zones or forest types. As most human populations have been historically concentrated on the coastal plains in the Greater and Lesser Antilles, lowland forests of all types have been 
Table 1. Forest areas in countries of the Insular Caribbean modified from Lugo et al. (1981)

\begin{tabular}{|c|c|c|c|c|c|c|c|}
\hline \multirow[b]{2}{*}{ Country } & \multirow[b]{2}{*}{$\begin{array}{l}\text { Total area } \\
\text { (ooos ha) }\end{array}$} & \multicolumn{6}{|c|}{$\%$ Forested (estimates from various sources) } \\
\hline & & $1920^{a}$ & $1964^{b}$ & $1974^{b}$ & 1978 & $1980 s$ & $1980 \mathrm{~s}$ \\
\hline Bahamas & 1,394 & 13 & 23.2 & 23.2 & - & - & $19.0^{\mathrm{h}}$ \\
\hline \multicolumn{8}{|l|}{ Greater Antilles } \\
\hline Cuba & 11,452 & 46 & 14.4 & 11.0 & - & $18.0^{d}$ & $12.7^{h}$ \\
\hline Dominican Republic & 4,873 & 77 & 22.6 & 22.7 & - & $10.1^{e}$ & $27.0^{\mathrm{h}}$ \\
\hline Haiti & 2,775 & 60 & 3.6 & 1.8 & $6.7^{c}$ & - & - \\
\hline Jamaica & 1,096 & 30 & 46.1 & 44.9 & - & $24 \cdot 3^{\mathrm{f}}$ & $35.5^{h}$ \\
\hline Puerto Rico & 890 & 20 & 13.3 & 14.2 & - & $34.0^{\mathrm{g}}$ & - \\
\hline Virgin Islands (U.K.) & 15 & - & 6.7 & 6.7 & - & - & - \\
\hline Virgin islands (U.S.A.) & 34 & - & 5.9 & 5.9 & - & - & - \\
\hline Subtotal & 21,135 & & & & & & \\
\hline Weighted average & 53 & 16.5 & $14 \cdot 4$ & - & - & 17.1 & 18.1 \\
\hline \multicolumn{8}{|l|}{ Lesser Antilles } \\
\hline Antigua & 44 & - & 13.6 & 15.9 & - & - & $10.2^{i}$ \\
\hline Barbados & 43 & - & 0 & o & - & - & o \\
\hline Dominica & 75 & - & 68.0 & 46.7 & - & - & $76.1^{i}$ \\
\hline Grenada & 34 & - & 11.8 & 11.8 & - & - & $27.8^{\mathrm{i}}$ \\
\hline Guadeloupe & 178 & 12 & 32.6 & 34.8 & - & - & - \\
\hline Martinique & 110 & - & 24.5 & 25.5 & - & - & - \\
\hline Montserrat & 10 & - & 20.0 & 40.0 & - & - & $40.0^{\mathrm{i}}$ \\
\hline Netherlands Antilles & 96 & - & o & 0 & - & - & - \\
\hline St Kitts-Nevis-Anguilla & 36 & - & 19.4 & 16.7 & - & - & $30.5^{i}$ \\
\hline St Lucia & 62 & - & 21.0 & 21.0 & - & - & $35 \cdot 5^{\mathrm{i}}$ \\
\hline St Vincent & 34 & - & $44 \cdot 1$ & 41.2 & - & - & $38.0^{\mathrm{i}}$ \\
\hline Trinidad and Tobago & 513 & 59 & 45.2 & 44.1 & - & $37.0^{\mathrm{h}}$ & $53 \cdot 3^{i}$ \\
\hline Subtotal & 1,235 & & & & & & \\
\hline Weighted average & - & 33.6 & 32.3 & - & - & - & 46.3 \\
\hline Total & 23,764 & & & & & & \\
\hline Weighted average & - & - & 17.7 & 15.8 & - & - & 20.9 \\
\hline
\end{tabular}

"Zon and Sparhawk (1923), 'bAO (1975), 'Ehrlich et al. (1985), 'Perera Puga and Rosabal González (1986), 'Martinez (1990), 'Anon. (1987), 'Birdsey and Weaver (1987), hFAO (1991), 'Chalmers (1990).

severely reduced (Beard 1949). This is particularly evident in the dry forests, which are restricted to the lowlands and have been extensively degraded by charcoal-cutting and overgrazing (e.g. Beard 1949, Hartshorn et al. 1981, Ehrlich et al. 1985). Within the Dominican Republic, Hartshorn et al. (1981) note that since the arrival of Europeans the pure pine forest has decreased in area by about $30 \%$ and the mixed pine-broadleaf forest by $70 \%$. They attribute this differential loss of Dominican forests to the lower elevation of the mixed forests, hence its accessibility for logging, and the better soils under the mixed forests. Steep topographic relief may also contribute to the retention of forest cover, as Lugo et al. (1981) showed that islands with steep topography have a larger proportion of forest than do flat islands. However, they note that the steeper sites also tend to be much wetter than more level sites and therefore less suitable for agriculture.

The deforestation trend has been reversed on several islands. For example, in the Bahamas broadleaf forest ("coppice") was extensively cut in the colonial period, whereas extensive pine cutting began at the beginning of the twentieth 
century and hence most existing forests are of secondary or tertiary origin (Campbell 1978). On Puerto Rico, native forest cover has increased from a low of $6 \%$ in the 1940 s to a current level of $32 \%$ (Birdsey and Weaver 1982). Puerto Rican forests gradually recovered because cropland and pasture were abandoned on eroded hillsides in the island's mountainous regions during a period of rapid industrialization. Similarly, forested areas in Cuba were reduced to $14 \%$ in 1959, but according to some estimates appear to have increased recently to approximately 18\% (Perera Puga and Rosabal González 1986).

Lugo et al. (1981) analysed some of the factors that affect deforestation on Caribbean islands and countries bordering the Caribbean. They concluded that increasing human population density decreases forest areas, and that with increased energy resources people become more efficient in their conversion of forests. This relationship can be further modified by trade policy, forest accessibility and type of life zone. In addition, frequent hurricanes and droughts, which are characteristic of the region (e.g. Faaborg et al. 1984, Faaborg and Arendt 1992), may further contribute to the degradation of remnant forest fragments.

\section{Future prospects for migrants wintering in the Caribbean}

The precarious condition of the remaining Caribbean forests suggests that the region faces an uncertain future as a wintering ground for terrestrial Nearctic migrants. As Caribbean habitats are modified, the suitability of the region for overwinter survival of Nearctic migrants will change depending on speciesspecific characteristics. The characteristics which predispose a particular species to severe population declines include limited geographic range, habitat specialization, restriction to vulnerable habitats, and small population size. These characteristics are summarized for the species which commonly winter in the region in Table 2.

Obviously, species which winter exclusively or primarily in the Bahamas and Caribbean are most vulnerable to habitat changes in the region. Thus, for several species this region is particularly critical as they winter(ed) nowhere else (Kirtland's Warbler, the extinct Bachman's Warbler), or occur primarily here and sporadically along the shoreline of the Caribbean basin (Cape May Warbler, Blackthroated Blue Warbler), or also in the south-eastern U.S.A. (Prairie and Palm Warblers) or Mexico and Central America (Northern Parula). For other species the region may represent a smaller portion of their winter range, which also may include Mexico, Central and South America: Yellow-throated Warbler, Wormeating Warbler, Swainson's Warbler, Black-and-white Warbler, Ovenbird, Northern Waterthrush, American Redstart, Yellow-rumped Warbler, Magnolia Warbler, Yellow-bellied Sapsucker, Black-throated Green Warbler, Indigo Bunting, Grey Catbird and Common Yellowthroat. Finally, most of the rare species detected in the region are vagrants whose primary winter range may include parts of Mexico, Central or South America: White-eyed Vireo, Yellow-throated Vireo, Kentucky Warbler, Hooded Warbler, Wilson's Warbler, Golden-winged Warbler, Blue-winged Warbler, Blackburnian Warbler, Yellow-breasted Chat, Chestnutsided Warbler, Tennessee Warbler, Wood Thrush and Grey-cheeked Thrush.

A migrant species with a geographically widespread winter distribution among various islands of the Caribbean will be at less risk to local habitat 
Table 2. Summary of traits of terrestrial Nearctic migrants which winter in the Bahamas and Greater Antilles (see Appendix for scientific names). Importance of the region refers to the estimated proportion of a species's population which winters in this region. Ratio of island groups/continental countries are based on listings in Rappole et al. (1983). All remaining traits were obtained from point count and mist-netting surveys in the Bahamas and Greater Antilles (Wunderle and Waide 1993). Habitat breadth refers to the distribution among different habitat types, and ranges from generalist, moderate specialist, specialist, and extreme specialist. Habitat type refers to successional stage and ranges from early to mid-succession; mid- to mature forest and edge; mature forest. Maximum count refers to the maximum percentage of 10-min point counts in which a species was detected in the specified habitat. Both habitats are shown when a tie occurred among the maximum counts. Initials under habitats are: A, Andros; C, Cuba; DR, Dominican Republic; GI, Great Inagua; J, Jamaica; NP, New Providence; PR, Puerto Rico.

\begin{tabular}{|c|c|c|c|c|c|c|}
\hline \multirow[b]{2}{*}{ Species } & \multicolumn{6}{|c|}{ Importance of region } \\
\hline & $\begin{array}{l}\text { Island } \\
\text { groups/ } \\
\text { continent } \\
\text { countries }\end{array}$ & $\begin{array}{l}\text { Habitat } \\
\text { value }\end{array}$ & $\begin{array}{l}\text { Habitat } \\
\text { breadth }\end{array}$ & $\begin{array}{l}\text { Habitat } \\
\text { types }\end{array}$ & $\begin{array}{l}\text { Maxi- } \\
\text { mum } \\
\text { count }\end{array}$ & $\begin{array}{l}\text { Habitat of } \\
\text { maximum } \\
\text { count }\end{array}$ \\
\hline Kirtland's Warbler & $1 / 0$ & $\begin{array}{l}\text { Very } \\
\text { high }\end{array}$ & Specialist (?) & $\begin{array}{l}\text { Mid-succ. } \\
\text { to mature }\end{array}$ & - & $\begin{array}{l}\text { Broadleaf } \\
\text { scrub }\end{array}$ \\
\hline Cape May Warbler & $5 / 1$ & $\begin{array}{l}\text { Very } \\
\text { high }\end{array}$ & $\begin{array}{l}\text { Moderate } \\
\text { specialist }\end{array}$ & $\begin{array}{l}\text { Mid-succ. } \\
\text { to forest }\end{array}$ & $37 \%$ & $\begin{array}{l}\text { Residential } \\
\text { (GI) }\end{array}$ \\
\hline Northern Parula ${ }^{a}$ & $7 / 3$ & High & $\begin{array}{l}\text { Moderate } \\
\text { specialist }\end{array}$ & $\begin{array}{l}\text { Mid-succ. } \\
\text { to forest }\end{array}$ & $37 \%$ & $\begin{array}{l}\text { Moist forest } \\
\text { (St John) }\end{array}$ \\
\hline $\begin{array}{l}\text { Black-throated Blue } \\
\text { Warbler }\end{array}$ & $6 / 3$ & High & $\begin{array}{l}\text { Moderate } \\
\text { specialist }\end{array}$ & $\begin{array}{l}\text { Mid-succ. } \\
\text { to forest }\end{array}$ & $77 \%$ & $\begin{array}{l}\text { Montane } \\
\text { secondary } \\
(\mathrm{PR})\end{array}$ \\
\hline Palm Warbler & $6 / 3$ & High & $\begin{array}{l}\text { Moderate } \\
\text { spec.-spec. }\end{array}$ & $\begin{array}{l}\text { Early-mid- } \\
\text { succession }\end{array}$ & $66 \%$ & $\begin{array}{l}\text { Brushy field } \\
\text { (A) }\end{array}$ \\
\hline Prairie Warbler & $6 / 3$ & High & $\begin{array}{l}\text { Moderate } \\
\text { specialist }\end{array}$ & $\begin{array}{l}\text { Early-mid- } \\
\text { succession }\end{array}$ & $33 \%$ & Pasture (J) \\
\hline $\begin{array}{l}\text { Yellow-throated } \\
\text { Warbler }\end{array}$ & $6 / 4$ & $\begin{array}{l}\text { Mod- } \\
\text { erate }\end{array}$ & Specialist & Pine forest & $25 \%$ & Pine (A) \\
\hline $\begin{array}{l}\text { Worm-eating } \\
\text { Warbler }\end{array}$ & $6 / 8$ & Low & Specialist & Forest & $7 \%$ & $\begin{array}{l}\text { Wet } \\
\text { limestone } \\
\text { forest }(\mathrm{J}) \\
\text { Montane } \\
\text { broadleaf } \\
\text { forest }(\mathrm{J})\end{array}$ \\
\hline Swainson's Warbler & $2 / 3$ & Low & Specialist & Forest & $b$ & $\begin{array}{l}\text { Mangrove (J) } \\
\text { Montane } \\
\text { broadleaf } \\
\text { forest }(\mathrm{J})\end{array}$ \\
\hline $\begin{array}{l}\text { Black-and-white } \\
\text { Warbler }\end{array}$ & $7^{/ 11}$ & Low & Generalist & Forest & $42 \%$ & Mangrove $(\mathrm{J})$ \\
\hline Ovenbird & $7 / 12$ & Low & Generalist & Forest & $18 \%$ & $\begin{array}{l}\text { Shade coffee } \\
\text { (J) }\end{array}$ \\
\hline $\begin{array}{l}\text { Northern } \\
\text { Waterthrush }\end{array}$ & $7 / 13$ & Low & $\begin{array}{l}\text { Extreme } \\
\text { specialist }\end{array}$ & $\begin{array}{l}\text { Mangrove } \\
\text { forest }\end{array}$ & $81 \%$ & Mangrove (J) \\
\hline American Redstart & $7 / 14$ & Low & Generalist & Forest & $58 \%$ & Mangrove $(\mathrm{J})$ \\
\hline $\begin{array}{l}\text { Yellow-rumped } \\
\text { Warbler }\end{array}$ & $6 / 8$ & Low & Generalist & $\begin{array}{l}\text { Early-mid- } \\
\text { succession }\end{array}$ & $3 \%$ & $\begin{array}{l}\text { Mixed scrub } \\
\text { pine (A) } \\
\text { Dry } \\
\text { limestone } \\
\text { scrub (A) }\end{array}$ \\
\hline
\end{tabular}


Table 2-continued

\begin{tabular}{|c|c|c|c|c|c|c|}
\hline \multirow[b]{2}{*}{ Species } & \multicolumn{6}{|c|}{ Importance of region } \\
\hline & $\begin{array}{l}\text { Island } \\
\text { groups/ } \\
\text { continent } \\
\text { countries }\end{array}$ & $\begin{array}{l}\text { Habitat } \\
\text { value }\end{array}$ & $\begin{array}{l}\text { Habitat } \\
\text { breadth }\end{array}$ & $\begin{array}{l}\text { Habitat } \\
\text { types }\end{array}$ & $\begin{array}{l}\text { Maxi- } \\
\text { mum } \\
\text { count }\end{array}$ & $\begin{array}{l}\text { Habitat of } \\
\text { maximum } \\
\text { count }\end{array}$ \\
\hline Magnolia Warbler & $6 / 8$ & Low & Generalist & Forest & $3 \%$ & $\begin{array}{l}\text { Mangrove (J) } \\
\text { Low second- } \\
\text { ary forest } \\
\text { (DR) }\end{array}$ \\
\hline $\begin{array}{l}\text { Yellow-bellied } \\
\text { Sapsucker }\end{array}$ & $5 / 8$ & Low & Generalist & Forest & $3 \%$ & $\begin{array}{l}\text { Mangrove (C) } \\
\text { and pine } \\
\text { (NP) }\end{array}$ \\
\hline $\begin{array}{l}\text { Black-throated Green } \\
\text { Warbler }\end{array}$ & $5 / 8$ & Low & Generalist & Forest & $21 \%$ & $\begin{array}{l}\text { Shade coffee } \\
\text { (J) }\end{array}$ \\
\hline Indigo Bunting & $5 / 8$ & Low & $\begin{array}{l}\text { Moderate } \\
\text { specialist }\end{array}$ & $\begin{array}{l}\text { Early-mid- } \\
\text { succession }\end{array}$ & $6 \%$ & $\begin{array}{l}\text { Brushy field } \\
\text { (A) }\end{array}$ \\
\hline Grey Catbird & $4 / 7$ & Low & Generalist & $\begin{array}{l}\text { Early-mid- } \\
\text { succession }\end{array}$ & $27 \%$ & $\begin{array}{l}\text { Brushy field } \\
\text { (A) }\end{array}$ \\
\hline $\begin{array}{l}\text { Common } \\
\text { Yellowthroat }\end{array}$ & $5 / 8$ & Low & $\begin{array}{l}\text { Moderate } \\
\text { specialist }\end{array}$ & $\begin{array}{l}\text { Early-mid- } \\
\text { succession }\end{array}$ & $71 \%$ & $\begin{array}{l}\text { Brushy field } \\
\text { (A) }\end{array}$ \\
\hline White-eyed Vireo & $2 / 4$ & $\begin{array}{l}\text { Very } \\
\text { low }\end{array}$ & Generalist & $\begin{array}{l}\text { Early-mid- } \\
\text { succession }\end{array}$ & $3 \%$ & Pasture (C) \\
\hline Hooded Warbler & $\mathrm{o} / 7$ & $\begin{array}{l}\text { Very } \\
\text { low }\end{array}$ & Specialist & Forest & $13 \%$ & $\begin{array}{l}\text { Moist forest } \\
\text { (St John) }\end{array}$ \\
\hline
\end{tabular}

${ }^{a}$ Here we follow AOU (1983) in treating Northern Parula Parula americana separately from Tropical Parula P. pitiayumi.

${ }^{b}$ Detected by mist-netting only.

perturbations than a species restricted to only a few islands. This is particularly true given the differences among islands in patterns of land-use, human population density and economies. At one extreme are those islands or nations with relatively little area devoted to agriculture and relatively low population density (e.g. the Bahamas, with 14 persons $/ \mathrm{km}^{2}$ ), or high population density with abandoned farmland returning to second-growth forest (Puerto Rico), in contrast to others with considerable land devoted to subsistence agriculture and with a high population density (Haiti, with 224 persons $/ \mathrm{km}^{2}$ ). Owing primarily to their high per-capita incomes, the Bahamas and Puerto Rico have almost no problems with forest degradation resulting from charcoal-cutting, in contrast to Hispaniola, Jamaica and now possibly Cuba (as a result of recent petroleum shortages). Therefore, as future patterns of land use vary among the islands, widespread species will be better "buffered" from these local disturbances than species wintering on fewer islands.

In similar fashion, species capable of using a wide array of habitats on an island will be potentially more resistant to future changes in land use. Therefore species such as Yellow-throated Warblers (pine specialists) and Northern Waterthrushes (mangrove specialists) are at greater risk to habitat changes in the Caribbean than habitat generalists such as Ovenbirds, American Redstarts and Black-and-white Warblers. Fortunately, most migrants wintering in this region are found in a relatively wide array of habitat types, or at least the breadth of habitats used is comparable, on average, to that used by residents (Wunderle and Waide 1993). 
Wide habitat breadth is an especially important adaptation, particularly when the mosaic of habitat types is constantly changing. Perhaps most important is a species's ability to utilize early successional sites - open pastures, brushy edges, ornamental plantings of residential areas, young second growth and forest edge - which will remain common habitats and consequently should sustain wintering populations of certain migrants on most of these islands for the near future (assuming that pesticide use does not widely increase). Therefore, species such as Palm Warblers, Common Yellowthroats, Prairie Warblers, Yellow-rumped Warblers, Cape May Warblers, Northern Parulas, Grey Catbirds and Indigo Buntings are likely to be at less risk than migrants requiring closedcanopy forest. Because of their limited areal extent, mature or old secondgrowth forests are at greatest immediate risk to destruction or degradation in the Caribbean. This would place forest dwellers at greatest risk, in descending order from extreme forest specialists (Northern Waterthrush), forest specialists (Worm-eating Warbler, Black-throated Green Warbler, Blue-grey Gnatcatcher, Yellow-throated Warbler and Swainson's Warbler), forest generalists (American Redstart, Black-and-white Warbler, Ovenbird) and even some mid-succession to mature forest species (Black-throated Blue Warbler).

The importance of a closed canopy is particularly evident when comparing migrant composition and abundance in coffee plantations with shade overstorey ("shade coffee") and those with no overstorey ("sun coffee") on Jamaica (Wunderle and Waide 1993). Although the two types of plantation were at different altitudes (shade at $300 \mathrm{~m}$; sun at 1,300 $\mathrm{m}$ ), we believe that the differences in species composition can largely be attributed to the degree of canopy cover, as most of the species missing from the sun coffee plantations were found in nearby montane broadleaf forest. Overall, total migrant detections in sun coffee $(72 \%$ of all points) was only slightly lower than in shade coffee ( $79 \%$ of all points), but the species richness in sun coffee was considerably lower (four species in 32 points) than in shade coffee ( 10 species in 28 points). Both Black-throated Blue Warblers and Common Yellowthroats were commoner in the sun coffee (44\% and $41 \%$ of all points, respectively) than in the shade coffee $(29 \%$ and $7 \%$ of all points, respectively). American Redstart detections were about the same in shade and sun coffee (7.1\% vs $9.0 \%$ of all points, respectively) while Prairie Warblers were more frequent in shade coffee $(17.9 \%$ vs $9.0 \%)$ and the remaining species were found only in the shade coffee: Black-and-white Warbler (21.4\%), Black-throated Green Warbler (21.4\%), Ovenbird (17.9\%), Chestnut-sided Warbler (10.7\%), Northern Parula (7.1\%) and Palm Warbler (3.6\%).

Thus it is evident that the overstorey makes a significant contribution to species richness and abundance of wintering forest-dwelling migrants, as previously cited by others (Robbins et al. 1989, Terborgh 1989, Askins et al. 1990). As these authors have noted (and we concur), the continuing conversion of shade coffee to sun coffee will be detrimental to most wintering migrants (and many resident species as well). In fact, more recent surveys by J.M.W. (unpublished data) in the Dominican Republic indicate that most sun coffee plantations are considerably more depauperate than those sampled in Jamaica. It is not likely that this conversion will be reversed, as farmers are responding to the spread of a coffee blight, which is particularly lethal to the traditional varieties of shaded coffee, and replacing it with sun-tolerant and more disease-resistant 
varieties of coffee. In many instances, however, the small farmer cannot afford to convert to sun coffee, which requires more fertilizers and pesticides, and therefore the land is put into pasture or small vegetable gardens (A. Helfenberger pers. comm.). The conversion from shade to sun coffee has progressed rapidly in Haiti (A. Helfenberger pers. comm.) and continues in the Dominican Republic (D. Abramo pers. comm., J.M.W. pers. obs.). This conversion provides support to our belief that wintering migrants that require a closed canopy are at greatest risk to future habitat changes in the Caribbean region.

Population size can be useful in evaluating extinction risk while measures of abundance might indicate the suitability of particular habitats. We therefore provide a summary of maximum counts (Table 2 ) to help evaluate the potential vulnerability of different species. However, as noted earlier, low detection rates of certain species are expected because they are vagrants or counts were made on the edge of their winter range. Caution too, needs to be exercised in evaluating the very high counts obtained in some habitats (e.g. montane second growth in Puerto Rico) as these may represent sites of high population turnover. It is currently unknown if high turnover indicates higher mortality than lower turnover, but if it does then habitats with lower conspecific densities might actually be the most suitable for some species.

Of the migrants which winter primarily in the Caribbean (Kirtland's Warbler, Cape May Warbler, Black-throated Blue Warbler, Palm Warbler, Prairie Warbler, Northern Parula) all except Kirtland's show traits which should help them to survive moderate levels of habitat disturbance on the wintering grounds. These traits include wintering on numerous islands, moderate habitat specialization, utilization of successional habitats, and moderate to high population densities. Unfortunately little is known of Kirtland's Warbler on its wintering grounds. The species has been found in low broadleaf scrub (Radabaugh 1974) with records (specimens or sight) scattered among the Bahama islands (Radabaugh 1974), Turks and Caicos Islands ( $P$. Bradley pers. comm.), and the Dominican Republic (Faanes and Haney 1989, W. Arendt pers. comm.). Therefore, it is possible that Kirtland's Warblers are vulnerable to disturbance on the wintering grounds, something which may have occurred in the past before the species was known to science (Rappole et al. 1983, Terborgh 1989).

\section{Recommendations}

Our recommendations are based on the likelihood that migrants requiring closed-canopy forests are at greatest risk to future land-use changes in the Bahamas and Caribbean. These recommendations simply reinforce previous recommendations to maintain forest cover in the region.

\section{Greater Antilles}

(1) Protection of existing forest lands of all types will benefit migrants, but mangrove forests, wet limestone forests and montane forests (both broadleaf or mixed broadleaf and pine) are particularly beneficial to forest-dwelling migrants that commonly winter in the Greater Antilles. 
Mangroves in the Greater Antilles were consistently rich in migrants as measured by total migrant detections, with the highest total migrant count, obtained by Wunderle and Waide (1993), in a mangrove forest on Jamaica. Although migrant abundance in mangroves declined with distance from the mainland, mangroves still had the highest counts in Puerto Rico, an island where overall migrant density tends to be low. Others have also noted the abundance of wintering migrants in mangrove forests (e.g. Hutto 1980, Wauer and Sladen 1992). Migrants most likely to benefit from protection of mangroves are Northern Waterthrush, Black-andwhite Warbler, American Redstart, Northern Parula, Ovenbird, Swainson's Warbler (Jamaica and Cuba), Yellow-bellied Sapsucker, Magnolia Warbler, Bluegrey Gnatcatcher, Prairie Warbler and Common Yellowthroat.

Wet limestone forests, common on the haystack hills of the karst regions of all the major Greater Antilles, are the only major moist forest types to have survived in the lowlands. While the mesic valleys, with relatively deep soils, have mostly been converted to agriculture, the limestone-covered slopes and peaks, with thin rocky soils, remain mostly forested. Therefore an opportunity remains to preserve or continue to protect remnants of this forest type, as found in the Cockpit Country of Jamaica and Los Haitises in the Dominican Republic. Migrants most likely to benefit from preservation of this forest type include Black-throated Blue Warbler, Ovenbird, American Redstart, Black-and-white Warbler, Northern Parula and Worm-eating Warbler.

Montane forests of broadleaf species in Jamaica and Puerto Rico and of mixed broadleaf and pine in Cuba and Hispaniola harbour a variety of migrants. Preservation of mature pine is important for the Yellow-throated Warbler, which is a pine specialist in the Caribbean. However, without broadleaf trees, or at least a broadleaf understorey, native pine forests in the Dominican Republic are relatively sterile in terms of migrants. Species most likely to benefit from preservation of montane broadleaf forests include Black-throated Blue Warbler, American Redstart, Blue-grey Gnatcatcher, Black-throated Green Warbler, Black-and-white Warbler, Northern Parula, Worm-eating Warbler, Ovenbird, Louisiana Waterthrush and Yellow-bellied Sapsucker.

(2) Forested buffer-zones with agroforestry plantations can help protect existing forest reserves and expand the extent of forest canopy available to canopy-dwelling migrants. A fine demonstration of this occurs at the reserve Ebano Verde in the Dominican Republic where shade coffee plantations adjoin the reserve, and reduce the potential negative impact of an abrupt forest edge.

(3) Existing forest reserves require forest guards to control illegal cutting and hunting and to assist in public education efforts. Charcoal-cutting was observed in every site sampled in the Dominican Republic, including the existing national parks and reserves, and in many forested sites in Jamaica. Forest guards should be given the training, authority and means to eliminate illegal cutting. Trained guards, too, can play a valuable role in educating the public in the values of existing forests.

(4) Efforts should be made to protect and encourage trees in shelterbelts and hedgerows as well as preserving forest fragments in agricultural areas. Agroforestry techniques should be encouraged and developed to integrate native trees into agricultural lands. 
(5) The sustainable, non-destructive use of existing unprotected forests should be promoted. Degraded pasturelands should be planted with fast-growing tree species to provide charcoal to reduce cutting pressure on remaining native forest fragments.

(6) Long-term support is needed for local NGOs involved in environmental education, land conservation and preservation. This should include financial support and training of conservation personnel. Turnover of resource managers, biologists and technicians is commonly high in the governments of the region, and the NGOs are often the only group capable of maintaining a consistent "long-term" conservation programme with experienced and trained personnel. Furthermore, adequate funding of NGO personnel may help combat the persistent "brain drain" problem of these developing countries, and may provide a pool of talent for future government conservation efforts. Funding should also be provided for local exchanges and consulting by nationals in their home countries.

(7) No Nearctic migrant programme in the Caribbean can be successful without the active involvement of Cuba. As the largest island, with high migrant densities, Cuba has one of the more successful conservation programmes in Latin America (Santana 1991). Furthermore, Cuba has some of the most active and capable ecologists and ornithologists in the Caribbean. All efforts should be made to assist the Cubans in their conservation efforts, and they should be included in all regional conservation programmes. A small grants programme would broaden interchange.

(8) Long-term monitoring of migrants (as well as endemics) should be initiated in both mesic and xeric forest habitats throughout the region. However, research will be needed to help us understand the potential causes of population changes (e.g. Faaborg and Arendt 1990).

\section{Bahamas}

The general recommendations listed above for the Greater Antilles also apply to the Bahamas, with the following specific recommendations:

(1) The most mesic coppice or limestone broadleaf scrub vegetation should be preserved, as this habitat maintains a high diversity of migrant species, particularly, in the northern Bahamas. Preservation of this habitat type will potentially benefit Kirtland's Warbler, Swainson's Warbler, Worm-eating Warbler, Black-throated Blue Warbler, American Redstart, Ovenbird, Cape May Warbler, Prairie Warbler, Palm Warbler, Blue-grey Gnatcatcher and Grey Catbird.

(2) Pines are important for wintering Yellow-throated Warblers in the northern Bahamas and when mixed with coppice will also harbour many of the species also found in coppice.

\section{Final recommendation}

Conservation strategies for wintering migrants in the tropics should be designed so as not to distract local conservationists from efforts to conserve endemics, many of which are more severely threatened than most migrants. Thus it is essential that all migrant conservation efforts be coupled with "priority" projects for endemic species or communities. 


\section{Acknowledgements}

Our fieldwork was supported by funds from the World Wildlife Fund-U.S. and the University of Puerto Rico. The assistance of numerous individuals is gratefully acknowledged and summarized in Wunderle and Waide (1993).

Appendix. Summary of terrestrial Nearctic migrants and the winter habitats in which they were detected during point counts and mist-netting in the Bahamas (Andros, Great Inagua, New Providence) and Greater Antilles (Cuba, Jamaica, Dominican Republic, Puerto Rico, St John).

Letters for habitat indicate: MAN, mangrove; DRF, dry forest or scrub; PAS, wooded pasture; LBR, lowland broadleaf forest; LSE, lowland second growth; PIN, pine; MBR, montane broadleaf forest; MSE, montane second growth; COP, coppice or broadleaf scrub; FIE, brushy field. Details and locations are provided in Wunderle and Waide (1993).

Species

Habitats

MAN DRF PAS LBR LSE PIN MBR MSE COP FIE

Sphyrapicus varius

Yellow-bellied Sapsucker

Polioptila caerulea

Blue-grey Gnatcatcher

Catharus minimus

Grey-cheeked Thrush

Hylocichla mustelina

Wood Thrush

Dumetella carolinensis

Grey Catbird

Vireo griseus

White-eyed Vireo

Vireo flavifrons

Yellow-throated Vireo

Vermivora pinus

Blue-winged Warbler

Vermivora peregrina

Tennessee Warbler

Parula americana

Northern Parula

Dendroica pensylvanica

Chestnut-sided Warbler

Dendroica magnolia

Magnolia Warbler

Dendroica tigrina

Cape May Warbler

Dendroica caerulescens

Black-throated Blue Warbler

Dendroica coronata

Yellow-rumped Warbler

Dendroica virens

Black-throated Green Warbler

Dendroica fusca

Blackburnian Warbler

Dendroica dominica

Yellow-throated Warbler

Dendroica discolor

Prairie Warbler

Dendroica palmarum

Palm Warbler
$X$

$\begin{array}{lll}x & x \\ x & x & x \\ x & x \\ & x\end{array}$

$\begin{array}{llll}x & x & x \\ x & x & \\ & x & \end{array}$

$x$

$\begin{array}{ccccccc} & & & x & x & & \\ x & x & & x & x & x & x \\ & x & x & & & & \end{array}$

$\mathrm{x} \quad \mathrm{x} \quad \mathrm{x} \quad \mathrm{x}-\mathrm{x}$

$\begin{array}{lllllll}X & X & X & X & X & X & X\end{array}$

$\begin{array}{lllllllllllllllllllllll}x & x & x & x\end{array}$

$\begin{array}{llllllll}\mathrm{x} & \mathrm{X} & \mathrm{X} & \mathrm{X} & \mathrm{x} & \mathrm{X} & \mathrm{x}\end{array}$

$x \quad x \quad x \quad x$

X

$\mathrm{x}$ 
Appendix. - continued

\begin{tabular}{|c|c|c|c|c|c|c|c|c|c|c|}
\hline \multirow[t]{2}{*}{ Species } & \multicolumn{10}{|c|}{ Habitats } \\
\hline & MAN & DRF & PAS & LBR & LSE & PIN & MBR & MSE & $\mathrm{COP}$ & FIE \\
\hline \multicolumn{11}{|l|}{ Mniotilta varia } \\
\hline Black-and-white Warbler & $x$ & $\mathrm{X}$ & & $x$ & $\mathrm{x}$ & $\mathrm{x}$ & $x$ & $x$ & $\mathrm{x}$ & \\
\hline \multicolumn{11}{|l|}{ Setophaga ruticilla } \\
\hline American Redstart & $x$ & $x$ & & $x$ & $\mathrm{x}$ & $x$ & $\mathrm{x}$ & $x$ & $x$ & $x$ \\
\hline \multicolumn{11}{|l|}{ Helmitheros vermivorus } \\
\hline Worm-eating Warbler & & $\mathrm{x}$ & & $x$ & $\mathrm{x}$ & & $x$ & & & \\
\hline \multicolumn{11}{|l|}{ Limnothlypis swainsonii } \\
\hline Swainson's Warbler & $x$ & & & & & & $x$ & & & \\
\hline \multicolumn{11}{|l|}{ Seiurus aurocapillus } \\
\hline Ovenbird & $\mathrm{X}$ & $\mathrm{x}$ & & $\mathrm{X}$ & $\mathrm{X}$ & $\mathrm{x}$ & $x$ & $\mathrm{x}$ & $\mathrm{X}$ & \\
\hline \multicolumn{11}{|l|}{ Seiurus noveboracensis } \\
\hline Northern Waterthrush & $x$ & & & $\mathrm{x}$ & & & & & & \\
\hline \multicolumn{11}{|l|}{ Seiurus motacilla } \\
\hline Louisiana Waterthrush & & & & $\mathrm{X}$ & & & $X$ & & & \\
\hline \multicolumn{11}{|l|}{ Oporornis formosus } \\
\hline Kentucky Warbler & $x$ & & & $\mathrm{x}$ & & $x$ & & & & \\
\hline \multicolumn{11}{|l|}{ Geothlypis trichas } \\
\hline Common Yellowthroat & $x$ & $x$ & $x$ & & $x$ & $x$ & $x$ & $x$ & $x$ & $x$ \\
\hline \multicolumn{11}{|l|}{ Wilsonia citrina } \\
\hline Hooded Warbler & & $\mathrm{x}$ & & $\mathrm{x}$ & $\mathrm{x}$ & & & & & \\
\hline \multicolumn{11}{|l|}{ Wilsonia pusilla } \\
\hline Wilson's Warbler & & & & & $\mathrm{x}$ & & & & & \\
\hline \multicolumn{11}{|l|}{ Icteria virens } \\
\hline Yellow-breasted Chat & & & & & $x$ & & & & & $\mathrm{X}$ \\
\hline \multicolumn{11}{|l|}{ Passerina cyanea } \\
\hline Indigo Bunting & & & & & $\mathrm{x}$ & & & & & $x$ \\
\hline \multicolumn{11}{|l|}{ Passerina ciris } \\
\hline Painted Bunting & & & & & $\mathrm{x}$ & & & & & $\mathrm{x}$ \\
\hline
\end{tabular}

\section{References}

AOU (1983) Check-list of North American birds. Sixth edition. American Ornithologists' Union.

Anon. (1987) Jamaica, country environmental profile. Kingston, Jamaica: Government of Jamaica, Ministry of Agriculture, Natural Resources Division.

Askins, R. A., Lynch, J. F. and Greenberg, R. (1990) Population declines in migratory birds in eastern North America. Pp.1-57 in D. M. Power, ed. Current ornithology. New York: Plenum Press.

Askins, R. A., Ewert, D. N. and Norton, R. L. (1992) Abundance of wintering migrants in fragmented and continuous forests in the U.S. Virgin Islands. Pp.197-206 in J. M. Hagan and D. W. Johnston, eds. Ecology and conservation of Neotropical migrant landbirds. Washington, D.C.: Smithsonian Institution Press,

Beard, J. S. (1949) The natural vegetation of the Windward and Leeward Islands. Oxford, U.K.: Clarendon Press.

Birdsey, R. A. and Weaver, P. L. (1987) The forest resources of Puerto Rico. For. Serv. Res. Bull., SO-85, New Orleans, La., So. For. Exp. Sta., USDA.

Campbell, D. G. (1978) The ephemeral islands: a natural history of the Bahamas. London: Macmillan Publishers.

Chalmers, W. S. (1990) FAO tropical forestry action plan for nine CARICOM countries. Rome: report of preparatory mission to FAO. 
Cruz, A. and Fairbain, P. (1980) Threats to Caribbean wildlife. Pp.438-444 in Forty-fifth North American Wildlife Conference. Washington, D.C.: American Wildlife Institute.

Ehrlich, M., Conway, F., Adrien, N., LeBeau, F., Lewis, L., Lauwerysen, H., Lowenthal, I., Mayda, Y., Paryski, P., Smucker, G., Talbot, J. and Wilcox, E. (1985) Haiti: Country Environmental Profile. USAID-Ehrlich No. 521-0122.

Emlen, J. T. (1977) Land bird communities of Grand Bahama Island: the structure and dynamics of an avifauna. American Ornithologists' Union (Orn. Monogr. 24).

Emlen, J. T. (1980) Interactions of migrants and resident land birds in Florida and Bahama pinelands. Pp.133-143 in A. Keast and E. S. Morton, eds. Migrant birds in the Neotropics: ecology, behavior, distribution, and conservation. Washington, D.C.: Smithsonian Institution Press.

Ewel, J. J. and Whitmore, J. L. (1973) The ecological life zones of Puerto Rico and the U.S. Virgin Islands. USDA Forest Service Research Paper ITF-18.

Faaborg, J. R. and Arendt, W. J. (1992) Rainfall correlates of bird population fluctuations in a Puerto Rican dry forest: a 15-year study. Ornitología Caribea 3: 10-19.

Faaborg, J. R., Arendt, W. J. and Kaiser, M. S. (1984) Rainfall correlates of bird population fluctuations in a Puerto Rican dry forest: a nine year study. Wilson Bull. 96: 575-593.

Faanes, C. A. and Haney, J. C. (1989) First record of Kirtland's Warbler from the Dominican Republic and additional bird observations. Carib. J. Sci. 25: 30-35.

FAO (1975) Production yearbook, 29. Rome: Food and Agricultural Organization of the United Nations.

FAO (1991) Forest resources assessment 1990. Rome: Food and Agricultural Organization of the United Nations.

Hamel, P. B. (1986) Bachman's Warbler: a species in peril. Washington, D.C.: Smithsonian Institution Press.

Hartshorn, G. (1983) Plants. Pp.118-183 in D. H. Janzen, ed. Costa Rican natural history. Chicago: University of Chicago Press.

Hartshorn, G., Antonini, G., Dubois, R., Harcharik, D., Heckadon, S., Newton, H., Quesada, C., Shores, J. and Staples, G. (1981) The Dominican Republic, Country Environmental Profile. U.S. Agency for International Development.

Holdridge, L. (1972) Life zones in Haiti. Carte: Ecologie d'Haiti. Organization of American States.

Hutto, R. L. (1980) Winter habitat distribution of migratory land birds in western Mexico, with special reference to small foliage-gleaning insectivores. Pp.181-203 in A. Keast and E. S. Morton, eds. Migrant birds in the Neotropics: ecology, behavior, distribution, and conservation. Washington, D.C.: Smithsonian Institution Press.

Hyslop, C. (1991) Neotropical migrants in Cuba. The Neotropical Migratory Bird Conservation Program, National Fish and Wildlife Foundation, Washington, D.C. 1: 2.

Jiménez, J. de J. (1959) A new catalog of Dominican Flora. IX International Botanical Congress, Montreal, Canada.

Keast, A. (1980) Synthesis: ecological basis and evolution of the Nearctic-Neotropical bird migration system. Pp. 559-576 in A. Keast and E. S. Morton, eds. Migrant birds in the Neotropics: ecology, behavior, distribution, and conservation. Washington, D.C.: Smithsonian Institution Press.

Lack, D. and Lack, P. (1972) Wintering warblers in Jamaica. Living Bird 11: 129-153.

Lanly, J. P. (1982) Tropical forest resources. Rome: Food and Agriculture Organization of the United Nations.

Little, E. L. and Woodbury, R. O. (1976) Trees of the Caribbean National Forest, Puerto Rico. U.S.D.A. For. Serv. Res. Pap. ITF-20. Inst. Trop. For., Rio Piedras, P.R.

Little, E. L., Woodbury, R. O. and Wadsworth, F. H. (1974) Trees of Puerto Rico and the Virgin Islands, 2. Washington, D.C.: United States Department of Agriculture Forest Service (Handbook 449). 
Lugo, A. E., Schmidt, R. and Brown, S. (1981) Tropical forests in the Caribbean. Ambio 10: $318-324$.

MacArthur, R. H. and Wilson, E. O. (1967) The theory of island biogeography. Princeton, NJ: Princeton University Press.

Martínez, E. (1990) Los bosques dominicanos. Santo Domingo, Rep. Dominicana: Horizontes de América.

Pashley, D. N. (1988a) Warblers of the West Indies, I. The Virgin Islands. Carib. J. Sci. 24: 11-22.

Pashley, D. N. (1988b) Warblers of the West Indies, II. The western Caribbean. Carib. J. Sci. 24: 112-126.

Pashley, D. N. (1990) Warblers of the West Indies, III. The Lesser Antilles. Carib. J. Sci. 26: 75-97.

Perera Puga, A. and Rosabal González, P. (1986) Sistema nacional de áreas protegidas de la República de Cuba. Taller Internacional sobre sistemas nacionales de áreas protegidas, Caracas, Venezuela. COMARNA, La Habana, Cuba.

Radabaugh, B. E. (1974) Kirtland's warbler and its Bahama wintering grounds. Wilson Bull. 86: 374-383.

Rappole, J. H. and Powell, G. (1986) The Hooded Warbler. Pp.827-853 in R. L. D. Silvestro, ed. Audubon Wildlife Report. New York, NY: National Audubon Society.

Rappole, J. H., Morton, E. S., Lovejoy, T. E. and Ruos, J. L. (1983) Nearctic avian migrants in the Neotropics. Washington, D.C.: U.S. Department of the Interior, Fish and Wildlife Services.

Robbins, C. S., Dowell, B. A., Sutton, R. L., Sutton, A. H. and Weyer, D. D. (1989) Use of agricultural habitats by avian migrants in Puerto Rico, Jamaica and Belize. Paper presented at Annual Meeting (16-19 August) of the Society for the Study of Caribbean Ornithology, Santo Domingo, Dominican Republic.

Santana, E. C. (1991) Nature conservation and sustainable development in Cuba. Conserv. Biol. 5: 13-16.

Terborgh, J. (1989) Where have all the birds gone? Princeton: Princeton University Press.

Terborgh, J. W. and Faaborg, J. R. (1980) Factors affecting the distribution and abundance of North American migrants in the eastern Caribbean region. Pp.145-155 in A. Keast and E. S. Morton, eds. Migrant birds in the Neotropics: ecology, behavior, distribution, and conservation. Washington, D.C.: Smithsonian Institution Press.

Wauer, R. H. and Sladen, F. W. (1992) Importance of Virgin Islands mangrove habitats to migrant and wintering birds. Ornitologia Caribea 3: 50-54.

Wilcove, D. S. and Robinson, S. K. (1990) The impact of forest fragmentation on bird communities in Eastern North America. Pp.319-331 in A. Keast, ed. Biogeography and ecology of forest bird communities. The Hague, Netherlands: SPB Academic Publishers.

Woods, C. A. (1989) Biogeography of the West Indies: past, present, and future. Gainsville, Florida: Sandhill Crane Press.

Wunderle, J. M. and Waide, R. B. (1993) Distribution of overwintering Nearctic migrants in the Bahamas and Greater Antilles. Condor 95: 904-933.

Zon, R. and Sparhawk, A. (1923) Forest resources of the world. New York: McGraw Hill.

JOSEPH M. WUNDERLE, JR

International Institute of Tropical Forestry, U.S.D.A. Forest Service, Box B, Palmer, PR 00721, U.S.A.

ROBERT B. WAIDE

Terrestrial Ecology Division, GPO Box 363682, University of Puerto Rico, San Juan, PR 00936, U.S.A. 